\title{
Faktor-Faktor Yang Mempengaruhi Penggunaan Informasi Akuntansi Pada UMKM (Survei Perusahaan Umkm Pdam Tirta Sejiran Setason Kab. Bangka Barat)
}

\author{
Siti Nurhayati Nafsiah \\ Fakultas Ekonomi dan Bisnis, Universitas Bina Darma \\ Email: siti_nurhayati@binadarma.ac.id \\ Raka Yudha Birahma \\ Fakultas Ekonomi dan Bisnis, Universitas Bina Darma \\ Email: rakayudhabirahma@gmail.com
}

\begin{abstract}
In general, Micro, Small and Medium Enterprises, or commonly called MSMEs, are one of the economic activities carried out by the majority of citizens in Indonesia. One that is important for UMKM is the use of accounting information, in which researchers conduct surveys in the West Bangka PDAM TSS. The UMKM problem consists of a number of problems, especially in small businesses such as the error of goods sent, bureaucratic processes or slow payment in government, inappropriate prices, late arrival of goods, and competition that is not complex or unhealthy. Then it is proven that the use of accounting information for UMKM owners, especially in small businesses, is irrelevant or not timely, so that the PDAM has difficulty developing. The purpose of this research is to determine the effect of whether or not the last level of education, scale of business, length of business, educational background, and accounting knowledge of the use of accounting information at UMKM. The population in this study is that all owners and employees of UMKM are 55 permanent employees of UMKM. For the study sample because the population is less than 100 people, the sample is the same in a population of 55 permanent UMKM employees. The data collection used is using questionnaires to UMKM owners and employees. The data analyzed are validity, reliability, descriptive statistics, normality test, multicollinearity, heteroscedasticity, multiple linear regression analysis, coefficient of determination test, simultaneous test and partial test. The results showed that for the simultaneous test or jointly the five variables had a significant effect on the use of accounting information at UMKM. Whereas for partial or individual tests that the variables of the last level of education, scale of business, length of business, and educational background the results did not significantly influence the use of accounting information at UMKM, while for other variables namely accounting knowledge the results had a significant effect on the use of information accounting at UMKM.
\end{abstract}

Keywords: Micro Small and Medium Enterprises (UMKM), Use of Accounting Information, Latest Education Level Business Scale, Business Length, Educational Background Accounting Knowledge.

\begin{abstract}
Abstrak
Secara umum, Usaha Mikro Kecil dan Menengah atau biasa disebut dengan UMKM adalah salah satu aktivita ekonomi yang dilakukan mayoritas warga negara di Indonesia. Salah satu yang menjadi penting bagi UMKM yaitu penggunaan informasi akuntansi, dimana peneliti melakukan surveynya di PDAM TSS Bangka Barat. Dalam permasalahan UMKM terdiri dari beberapa permasalahan, terutama di usaha kecil seperti kesalahan barang yang dikirim, proses biroklasi atau pembayaran yang lambat di pemerintahan, harga yang tidak sesuai, barang yang terlambat datang, dan persaingan yang tidak kompotitif atau tiak sehat. Maka hal tersebut terbukti bahwa penggunaan informasi akuntansi pada pemilik UMKM terutama di usaha kecil tidaklah relevan atau tidak tepat waktu, sehingga pihak PDAM tersebut menjadi kesulitan untuk bisa berkembang. Tujuan dari penelitia ini yaitu untuk mengetahui berpengaruh atau tidaknya jenjang pendidikan terakhir, skala usaha, lama usaha, latar belakang pendidikan, dan pengetahuan akuntansi terhadap penggunaan informasi akuntansi pada UMKM. Populasi dalam penelitian tersebut yaitu seluruh pemilik dan karyawan UMKM berjumlah 55 karyawan tetap UMKM. Untuk sampel penelitian dikarenakan populasinya kurang dari 100 orang, maka sampelnya sama di populasi sebanyak 55 karyawan tetap UMKM. Pengumpulan data yang digunakan yakni menggunakan penyebaran kuesioner kepada pemilik dan karyawan UMKM. Data-data yang dianalisis yaitu uji validitas, reliabilitas, statistik deskriptif, uji
\end{abstract}




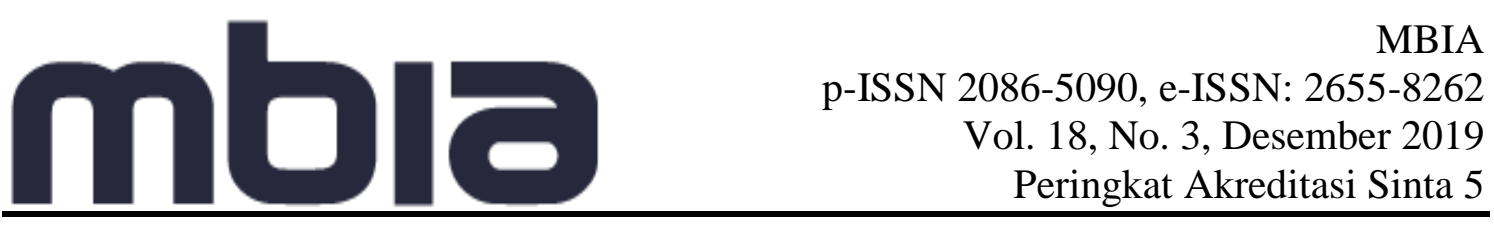

normalitas, multikoliniearitas, heteroskedastisitas, analisis regresi linear berganda, uji koefisien determinasi, uji simultan dan uji parsial. Hasil penelitian menunjukan bahwa untuk uji simultan atau secara bersama-sama kelima variabel bersifat berpengaruh signifikan terhadap penggunaan informasi akuntansi pada UMKM. Sedangkan untuk uji parsial atau secara sendiri-sendiri bahwa variabel jenjang pendidikan terakhir, skala usaha, lama usaha, dan latar belakang pendidikan hasilnya tidak berpengaruh signifikan terhadap penggunaan informasi akuntansi pada UMKM, sementara itu untuk variabel lainnya yaitu pengetahuan akuntansi hasilnya berpengaruh signifikan terhadap penggunaan informasi akuntansi pada UMKM.

Kata Kunci: Penggunaan Informasi Akuntansi, Skala Usaha, Lama Usaha, Latar Belakang Pendidikan, Pengetahuan Akuntansi.

\section{Pendahuluan}

Seiring berjalanya waktu, permasalahan yang terjadi di Usaha Mikro Kecil dan Menengah atau disebut dengan singkatan UMKM di negara Indonesia menjadi perhatian pemerintah. Hal ini dikarenakan munculnya banyak pesaing-pesaing baru secara global dan juga banyaknya permasalahan yang terjadi seperti menciptakan brand dan desain, sehingga UMKM di Indonesia menjadi kalah bersaing dengan Negara lainnya. Pada tahun 2019, jumlah UMKM di Indonesia saat ini sudah mencapai sekitar 56 juta dengan kompleks permasalahan yang ada. Hal ini dikhawatirkan akan mengalami kegagalan serta kerugian yang lumayan besar baik di peruahaan kecil maupun di perusahaan menengah dalam mengembangkan usaha tersebut (Farras, 2019).

Secara umum, UMKM adalah salah satu aktivita ekonomi yang dilakukan mayoritas warga negara di Indonesia. Menurut (UU No. 20 Tahun 2008), UMKM bertujuan menumbuhkan dan mengembangkan usahanya dalam rangka membangun perekonomian nasional berdasarkan demokrasi ekonomi dan berkeadilan. Berdasarkan (Kementrian Koperasi atau KK Serta UMKM, 2018), mengatakan bahwa jumlah unit usaha UMKM di indonesia pada tahun 20187 mencapai sekitar 62.922.617 unit dan tenaga kerjanya sebesar 116.673.416 orang. Berdasarkan nilai tersebut, maka terbukti bahwa perekonomian di Indonesia semakin berkembang dari tahun ke tahun dan akan semakin bagus jika UMKM di Indonesia tidak mengalami permasalahan sehingga terindar dari kondisi krisis yang dihadapinya.

Secara umum, informasi akuntansi merupakan suatu alat yang dipakai bagi pengguna informasi akuntansi akan pengambilan keputusan, khususnya pelaku bisnis (Nicholls and Holmes, 1998). Penggunaan informasi akuntansi digunakan untuk perencanaan strategis, pengawasan manajemen dan pengawasan operasional. Menurut pemerintah maupun komunitas akuntansi, mereka telah menegaskan bahwa informasi akuntansi bagi UMKM sangatlah penting dalam melakukan pencatatan maupun peyelenggaraan.

Badan Usaha Milik Daerah (BUMD) yaitu suatu bentuk untuk melaksanakan pembangunan daerah melalui peayanan jasa kepada masyarakat, penyelenggaraan kemanfaatan umum, dan peningkatan penghasilan pemerintah daerah. Salah satu yang menjadi bagiannya yaitu PDAM Tirta Sejiran Setason Kab. Bangka Barat, dimana penulis memfokuskan diri pada bagian pemilik dan karyawan UMKM.

Dibalik kerja sama antara pemilik UMKM dan PDAM, terdapat beberapa permasalahan yang harus dihadapi seperti kesalahan barang yang dikirim, harga yang tidak sesuai, dan 


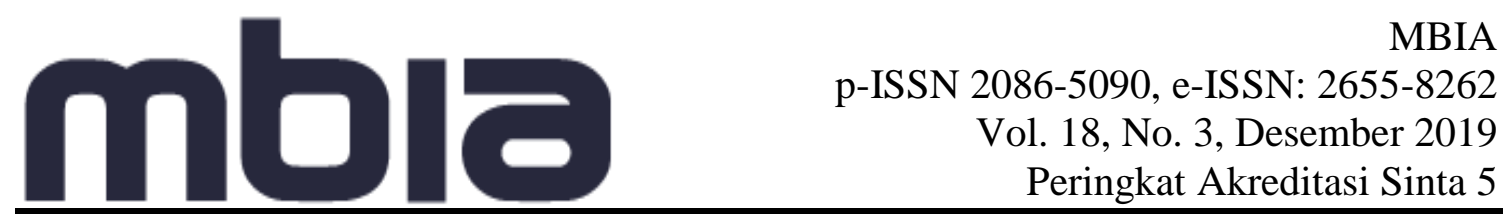

persaingan yang tidak kompetitif dan tidak sehat. Berikut berupa tabel untuk memperkuat permasalaha tersebut.

\begin{tabular}{|l|l|}
\hline Tahun & Jumlah \\
\hline 2017 & $\mathrm{Rp} 684.539 .031$ \\
\hline 2018 & $\mathrm{Rp} 684.480 .500$ \\
\hline
\end{tabular}

Berdasarkan hasil di atas maka terbukti bahwa informasi akuntansi pada pemilik UMKM terutama di usaha kecil tidaklah relevan dan tidak tepat waktu, sehingga pihak PDAM tersebut menjadi kesulitan untuk bisa berkembang. Permasalahan penggunaan informasi akuntansi membuat pemilik di UMKM menjadi kewalahan dalam menjalankan bisnisnya.

Berdasarkan permasalahan di atas, bahwa penulis mengembangkan penelitian ini dari penelitian (Aufar, 2013), dimana hasil tersebut menunjukkan bahwa variabel jenjang pendidikan terakhir, ukuran usaha, lama usaha, dan latar belakang pendidikan hasilnya berpengaruh signifikan terhadap penggunaan informasi akuntansi pada UMKM baik secara simultan maupun secara parsial.

\section{Literature Review}

\subsection{Pengertian UMKM}

Menurut (Rijanto, 2015) Usaha Mikro, Kecil, dan Menengah (UMKM) mempunyai peran penting dan strategis dalam pembangunan ekonomi nasional. Selain berperan dalam pertumbuhan ekonomi dan penyerapan tenaga kerja, UMKM juga berperan dalam mendistribusikan hasil-hasil pembangunan. UMKM juga telah terbukti tidak berpengaruh terhadap krisis . Ketika krisis menerpa pada periode tahun 1997-1998, hanya UMKM yang mampu tetap berdirih kokoh.

\subsection{Pengertian Informasi}

Menurut (George and Wiliam, 2000) dalam (Wulandari, 2016) informasi adalah suatu data yang tergarap yang menyebabkan dapat dijadikan bagian umum untuk menghasilkan suatu keutusan, dalam bidang usaha, informasi tersebut memiliki definisi yang jauh lebih berharga yakni sebagai pengetahuan umum untuk dilakukan pengambilan suatu keputusan,informasi usaha mendukung untuk memastikan suatu kesimpulan saat ini maupun dimasa yang akan mendatang agar mencapai kehendak perusahaan.

\subsection{Pengertian Akuntansi}

Menurut (Bahri, 2016) mengatakan bahwa akuntansi adalah seni pencacatan, penggolonggan, pengikhtisaran, dan pelaporan atas suatu transaksi dengan cara sedemikian rupa, sistematis dari segi isi, dan berdasarkan standar yang diakui umum. Oleh karena itu, pihak yang berkepentingan atas perusahaan dapat mengetahui posisi keuangan perusahaan serta hasil operasi pada setiap waktu yang diperlukan, sehingga dapat mengambil maupun pemilihan dari berbagai tindakan alternative di bidang ekonomi. 


\subsection{Pengertian Informasi Akuntansi}

Menurut (Bekaoui, 2000) dalam (Wulandari, 2016) menyatakan bahwa informasi akuntansi merupakan suatu informasi kuantitatif berisikan entitas ekonomi yang berguna akan pengambilan kesimpulan ekonomi untuk memastikan pilihan-pilihan diantaranya alternative-alternatif berupatindakan penggunaan informasi akuntansi tersebut buat perancangan strategis, pengamatan manajemen, serta pengamatan operasional.

\subsection{Laporan Keuangan}

Menurut (Hery, 2015) dalam (Oktasari, 2018) laporan keuangan pada dasarnya adalah hasil dari proses akuntansi yang dapat digunakan sebagai alat untuk mengkomunikasikan data keuangan atau aktivitas perusahaan kepada pihak-pihak yang berkepentingan. Dengan kata lain laporan keuangan ini berfungsi sebagai alat informasi yang menghubungkan perusahaan dengan pihak-pihak yang berkepentingan, yang menunjukkan kondisi kesehatan keuangan perusahaan dan kinerja perusahaan.

\section{Metodologi Penelitian}

Objek dalam penelitian ini yaitu dilaksanakan di UMKM dimana merupakan perusahaan UMKM di PDAM Tirta Sejiran Setason Bangka barat. Metode penelitian yang digunakan dalam penelitian ini yaitu menggunakan metode kuantitaif. Untuk jenis data yang dipakai terdiri dari dua, pertama yaitu data primer berupa kuesioner dan yang kedua yaitu data sekunder berupa dokumen-dokumen yang berhubungan dengan judul penelitian ini seperti buku, jurnal, dan internet. Untuk populasi dalam suatu penelitian yakni seluruh pemimpin dan karyawan UMKM berjumlah 55 karyawan tetap UMKM. Sementara untuk sampel penelitiannya, dikarenakan populasi penelitian tersebut kurang dari seratus orang maka sampel yang diambil sama berada si populasi yaitu berjumlah 55 karyawan tetap UMKM. Untuk metode pengumpulan data, sebelumya telah dijelaskan di jenis data primer yaitu menggunakan kuesioner, dimana kuesioner itu disebarkan kepada responden, kemudian diisi atau dijawab oleh responden berupa jenjang pendidikan terakhir, skala usaha, lama usaha, latar belakang pendidikan, pengetahuan akuntansi, dan penggunaan informasi akuntansi.

Dalam metode analisis data, penulis menggunakan alat bantu yaitu pengelolahan data SPSS dengan versi 25 . Ada beberapa metode analisis yang akan diuji, diantaranya yaitu uji validitas dan uji reliabilitas, statistik deskriptif, pengujian asumsi klasik yang terdiri dari uji normaitas, uji multikolinearitas, uji heteroskedastisitas, analisis regresi linear berganda, dan pengujian hipotesis yang terdiri dari uji koefisien determinasi $\left(\mathrm{R}^{2}\right)$, uji simultan (F-test), uji parsial (t-test).

\section{Hasil dan Pembahasan}

Pada bagian ini akan disajikan hasil penelitian dan pembahasan yang diperoleh dari penyebaran kuesioner kepada respoden sebagai sumber databdalam penelitian ini. Kuesioner terdapat dalam 29 buah pertanyaan dengan perincian 1 butir pertanyaan berupa jenjang pendidikan terakhir, 3 buah pertanyaan berupa skala usaha, 1 buah pertanyaan berupa lama usaha, 1 buah pertanyaan berupa latar belakang pendidian, 9 buah pertanyaan berupa pengetahuan akuntansi, dan 14 buah pertanyaan berupa pernggunaan informasi akuntansi. 


\section{Hasil Uji Validitas}

Pengujian tersebut dilakukan untuk melihat apakah alat pengukuran tersebut dirancang dalam kuesioner yaitu mengukur valid atau tidaknya suatu penelitian. Berikut berupa hasil uji validitas berupa variabel pengetahuan akuntansi dan penggunaan informasi akuntansi.

\begin{tabular}{|l|l|l|l|}
\hline $\begin{array}{l}\text { BUTIR } \\
\text { PERTANYAAN }\end{array}$ & R Hitung & $\begin{array}{l}\text { R Tabel } \\
\mathbf{5 \%})\end{array}$ & KETERANGAN \\
\hline PA1 & 0,412 & 0,279 & VALID \\
\hline PA2 & 0,648 & 0,279 & VALID \\
\hline PA3 & 0,490 & 0,279 & VALID \\
\hline PA4 & 0,634 & 0,279 & VALID \\
\hline PA5 & 0,668 & 0,279 & VALID \\
\hline PA6 & 0,793 & 0,279 & VALID \\
\hline PA7 & 0,778 & 0,279 & VALID \\
\hline PA8 & 0,685 & 0,279 & VALID \\
\hline PA9 & 0,617 & 0,279 & VALID \\
\hline
\end{tabular}

Sumber: Data Diolah, 2019

\begin{tabular}{|l|l|l|l|}
\hline $\begin{array}{l}\text { BUTIR } \\
\text { PERTANYAAN }\end{array}$ & R Hitung & $\begin{array}{l}\text { R Tabel } \\
\mathbf{( 5 \% )}\end{array}$ & KETERANGAN \\
\hline PIA 1 & 0,631 & 0,279 & VALID \\
\hline PIA 2 & 0,567 & 0,279 & VALID \\
\hline PIA 3 & 0,552 & 0,279 & VALID \\
\hline PIA 4 & 0,615 & 0,279 & VALID \\
\hline PIA 5 & 0,622 & 0,279 & VALID \\
\hline PIA 6 & 0,576 & 0,279 & VALID \\
\hline PIA 7 & 0,587 & 0,279 & VALID \\
\hline PIA 8 & 0,662 & 0,279 & VALID \\
\hline PIA 9 & 0,672 & 0,279 & VALID \\
\hline PIA 10 & 0,760 & 0,279 & VALID \\
\hline PIA 11 & 0,489 & 0,279 & VALID \\
\hline PIA 12 & 0,536 & 0,279 & VALID \\
\hline PIA 13 & 0,577 & 0,279 & VALID \\
\hline PIA 14 & 0,552 & 0,279 & VALID \\
\hline
\end{tabular}

Sumber: Data Diolah, 2019

Berdasarkan hasil uji validitas yaitu variabel pengetahuan akuntansi terdiri dari 9 pertanyaan, dan penggunaan informasi akuntasni terdiri dari 14 pertanyaan maka hasil tersebut dinyatakan valid, dikarenakan hasil dari $\mathrm{R}_{\text {hitung }}$ bersifat lebih besar dibandingkan $\mathrm{R}_{\text {tabel. }}$ Sehingga telah memenuhi kriteria validitas.

\section{Hasil Uji Reliabilitas}

Uji reliabilitas bisa digunakan secara bersama-sama kedalam semua item pertanyaan untuk lebih dari satu variabel. Hal tersebut merupakan hasil pengujian reliabilitas dalam variabel pengetahuan akuntansi dan penggunaan informasi akuntansi. 


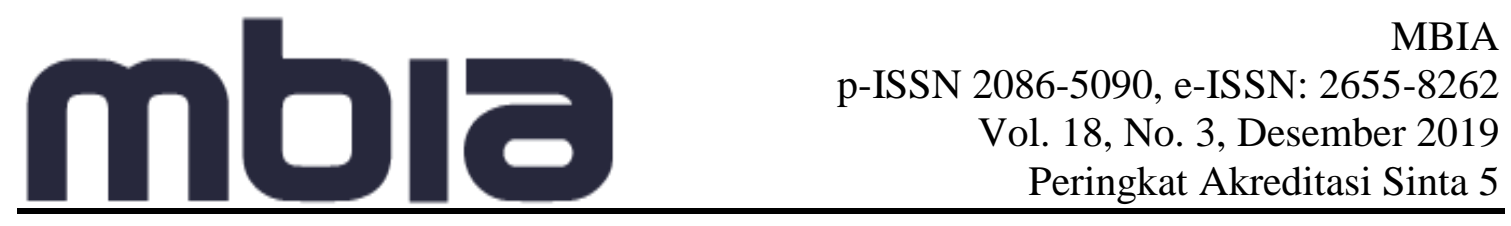

\begin{tabular}{|l|l|l|l|l|}
\hline $\begin{array}{l}\text { No. } \\
\text { Item }\end{array}$ & Nama Variabel & $\begin{array}{l}\text { Cronbach's } \\
\text { Alpa }\end{array}$ & $\begin{array}{l}\text { Cronbach's } \\
\text { Alpa Based On } \\
\text { Standardized } \\
\text { Item }\end{array}$ & $\begin{array}{l}\text { N of } \\
\text { Items }\end{array}$ \\
\hline 1. & $\begin{array}{l}\text { Pengetahuan } \\
\text { Akuntansi } \\
(X 5)\end{array}$ & 0,818 & 0,279 & 9 \\
\hline 2. & $\begin{array}{l}\text { Penggunaan } \\
\text { Informasi Akuntansi } \\
(Y)\end{array}$ & 0,863 & 0,279 & 14 \\
\hline
\end{tabular}

Sumber: Data Diolah, 2019

Berdasarkan hasil pengujian reliabilitas, dapat dilihat bahwa nilai cronbach's alpa yaitu pengetahuan akuntansi dan penggunaan informasi akuntansi bersifat tinggi dan dapat disimpulkan bahwa kedua variabel tersebut sudah memenuhi kriteria reliabel.

\section{Hasil Statistik Deskriptif}

Pengujian ini dipakai untuk memeperlihatkan deskripsi berupa beberapa nilai angka seperti angka minimum, maksimum, dan mean. Berikut berupa hasil sampelnya.

\begin{tabular}{|l|l|l|l|l|}
\hline & N & Minimum & Maximum & Mean \\
\hline Jenjang Pendidikan Terakhir & 55 & 1,000 & 3,000 & 2,58182 \\
\hline Skala Usaha & 55 & 1,000 & 3,000 & 2,06340 \\
\hline Lama Usaha & 55 & 2,000 & 4,000 & 2,74545 \\
\hline Latar Belakang Pendidikan & 55 & 1,000 & 4,000 & 3,30909 \\
\hline Pengetahuan Akuntansi & 55 & 1,000 & 5,000 & 3,85455 \\
\hline Penggunaan Informasi Akuntansi & 55 & 1,000 & 5,000 & 3,74545 \\
\hline Valid N (listwise) & 55 & & & \\
\hline
\end{tabular}

Dapat dilihat dari tabel diatas, bahwa untuk jenjang pendidikan terakhir rata-rata yang dijawab oleh rsponden yaitu 2,581182. Untuk skala usaha rata-rata yang dijawab oleh responden yaitu 2,06340. Untuk lama usaha rata-rata yang dijawab oleh responden yaitu 2,74545 . Untuk latar belakang pendidikan rata-rata yang dijawab oleh responden yaitu 3,30909. Untuk pengetahuan akuntansi rata-rata yang dijawab oleh responden yaitu 3,85455. Dan untuk penggunaan informasi akuntansi rata-rata yang dijawab oleh responden yaitu 3,74545 .

\section{Hasil Uji Normalitas}

Tujuan dari uji tersebut yaitu untuk melihat apakah data yang diperoleh bersifat berdistribusi normal atau bukan. Penulis menggunakan uji normal p-p plot of regression, berikut berupa gambarnya. 


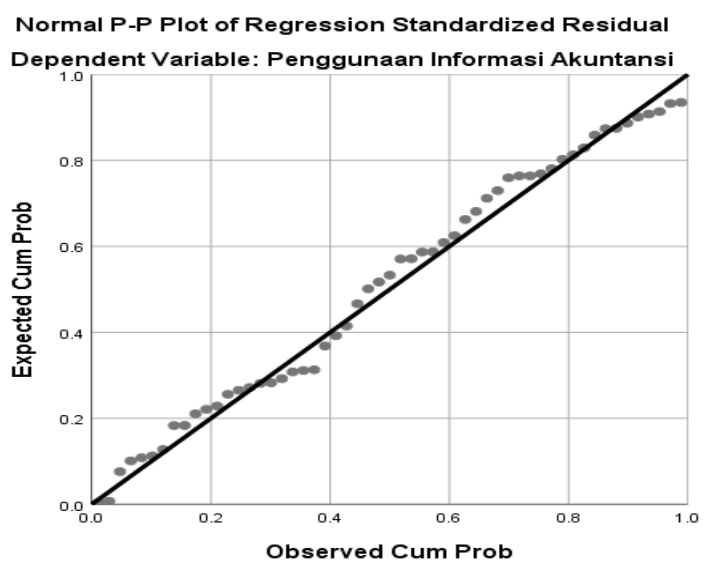

Sumber: Output SPSS, 2019

Dapat dilihat dari gambar diatas, bahwa hasil tersebut menunjukkan berdistribusi normal, dikarenakan titik-titik tersebut mengikuti garis diagonal mulai dari awal sampai akhir dan saling menyambung satu sama lain, selain itu titik-titik tersebut tidak melakukan penyebaran baik penyebaran jauh ke atas maupun kebawah. Sehingga terlihat jelas bahwa hasilnya berdistribusi normal.

\section{Hasil Uji Multikolinearitas}

Untuk uji tersebut, ada dua nilai yang harus diperhatikan. Pertama nilai tolerance harus lebih dari 0,100, kedua nilai VIF harus kurang dari 10. Berikut berupa hasilnya, yakni.

\begin{tabular}{|ll|l|l|}
\hline \multirow{2}{*}{ Model } & \multicolumn{2}{|c|}{ Collinearity Statistics } \\
\cline { 3 - 4 } & & Tolerance & VIF \\
\hline & (Constant) & & \\
& Jenjang Pendidikan Terakhir &, 356 & 2,807 \\
& Skala Usaha &, 184 & 5,446 \\
& Lama Usaha &, 197 & 5,084 \\
& Latar Belakang Pendidikan &, 292 & 3,430 \\
& Pengetahuan Akuntansi &, 760 & 1,315 \\
\hline
\end{tabular}

Sumber: Output SPSS, 2019

Dapat dilihat dari tabel diatas, bahwa hasilnya tidak terjadi multikolinearitas. Hal ini dapat terjadi dikarenakan seluruh nilai tolerance hasilnya lebih dari 0,100, sedangkan seluruh nilai VIF hasilnya kurang dari 10. Sehingga jelas bahwa tidak adanya masalah dalam uji ini.

\section{Hasil Uji Heteroskedastisitas}

Tujuan dari uji tersebut yaitu mengetahui adakah ketidaksamaan antara satu pengamatan ke pengamatan lainnya. Penulis mengunakan uji scatterplot untuk melihat grafik atau gambar yaitu hasilnya bersifat menyebar atau tidak. Berikut berupa gambarnya. 

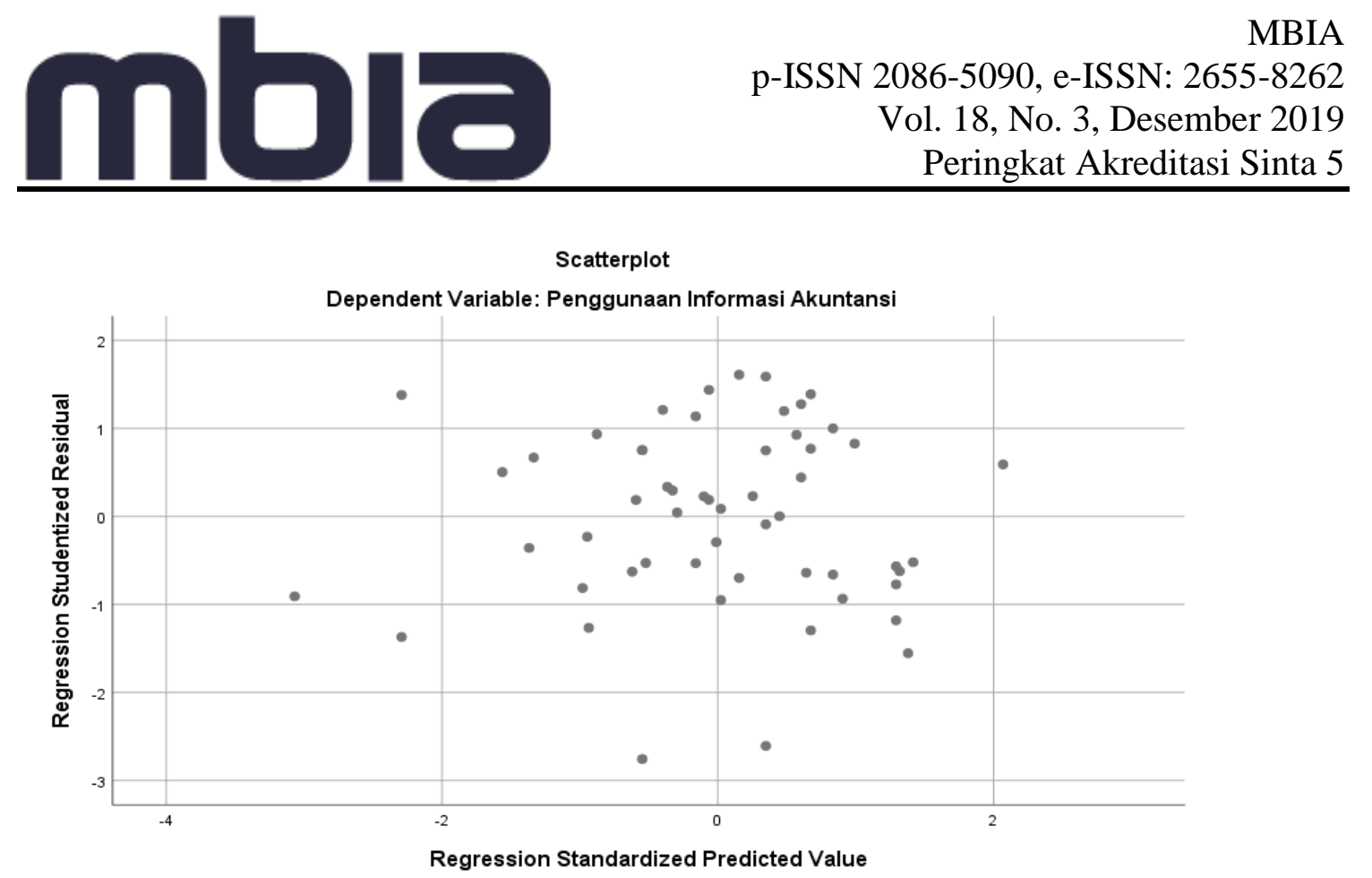

Sumber: Output SPSS, 2019

Setelah dilihat pada gambar diatas, maka dapat diketahui bahwa hasilnya yaitu titik-titik tersebut mereka melakukan penyebaran ke segala arah baik ke atas, bawah, kesebelah kiri, maupun kanan. Selain itu tidak terdapat pola-pola tertentu seperti berbentuk bulat, bergaris, maupun bergelombang. Sehingga dapat disimpulkan tidak terjadi heteroskedastisitas dalam penelitian,dan bisa dilanjutkan ke pengujian selanjutnya.

\section{Analisis Regresi Linear Berganda}

Tujuan dari pengujian ini yaitu melihat hubungan satu variabel ke variabel lainnya berupa berapa harga dari tiap-tiap variabel yang didapatkan. Berikut berupa hasilnya, yakni.

$$
Y=23,202+-0,359 X_{1}+-0,274 X_{2}+-2,131 X_{3}+0,426 X_{4}+1,098 X_{5}+e
$$

Untuk variabel jenjang pendidikan terakhir mendapatkan nilai sebesar -0,359 yang bearti bila terjadi kenaikan sebesar 1 (satuan) maka terjadi penurunan sebesar yang disebutkan. Untuk variabel skala usaha mendapatkan nilai sebesar $-0,274$ yang bearti bila terjadi kenaikan sebesar 1 (satuan) maka terjadi penurunan sebesar yang disebutkan. Untuk variabel lama usaha mendapatkan nilai sebesar -2,131 yang bearti bila terjadi kenaikan sebesar 1(satuan) maka terjadi penurunan sebesar yang disebutkan. Untuk variabel latar belakang pendidikan mendapatkan nilai sebesar 0,426 yang bearti bila terjadi kenaikan sebesar 1 (satuan) maka terjadi kenaikan sebesar yang disebutkan, namun masih bersifat rendah. Untuk variabel pengetahuan akuntansimendapatkan nilai sebesar 1,098 yang bearti bila terjadi kenaikan sebesar 1 (satuan) maka terjadi kenaikan sebesar yang disebutkan.

\section{Hasil Uji Koefisien Determinasi $\left(\mathbf{R}^{\mathbf{2}}\right)$}

Tujuan dari uji tersebut yaitu melihat seberapa tingginya variabilitas variabel dependen yang bisa dijelaskan dalam variabel bebasnya. Berikut berupa hasilnya, yakni. 
MBIA
p-ISSN 2086-5090, e-ISSN: 2655-8262
Vol. 18, No. 3, Desember 2019
Peringkat Akreditasi Sinta 5

Model Summary
\begin{tabular}{|l|l|l|l|l|}
\hline Model & R & R Square & $\begin{array}{l}\text { Adjusted } \\
\text { Square }\end{array}$ & $\begin{array}{l}\text { Std. Error of } \\
\text { the Estimate }\end{array}$ \\
\hline 1 & $.761^{\mathrm{a}}$ & .578 & .535 & 5.07321 \\
\hline
\end{tabular}

Sumber: Hasil Output SPSS, 2019

Setelah dilihat dari tabel diatas, maka dapat diketahui bahwa nilai adjusted sebesar 0,535. Bearti 53.5\% variabel dependen dijelaskan ke variabel independen. Sementara sisanya di jelaskan ke variabel luar pemahaman penelitian.

Hasil Uji Simultan (F-test)

Tujuan dari pengujian tersebut untuk membuktikan apakah secara bersama-sama atau secara simultan seluruh variabel bebas berpengaruh atau tidaknya terhadap variabel terikat. Berikut berupa hasilnya, yakni.

\begin{tabular}{|c|c|c|c|c|c|c|}
\hline Model & & $\begin{array}{|ll|}\text { Sum } & \text { of } \\
\text { Squares } & \\
\end{array}$ & Df & \begin{tabular}{|l} 
Mean \\
Square
\end{tabular} & $\mathbf{F}$ & Sig. \\
\hline \multirow[t]{3}{*}{1} & Regression & 1730.500 & 5 & 346.100 & $\begin{array}{l}13.44 \\
7\end{array}$ & $.000^{\mathrm{b}}$ \\
\hline & Residual & 1261.136 & 49 & 25.737 & & \\
\hline & Total & 2991.636 & 54 & & & \\
\hline
\end{tabular}

Sumber: Output SPSS, 2019

Setelah dilihat dari tabel diatas, maka jelas bahwa secara bersama-sama atau simultan seluruh variabel yang ada atau kelima variabel tersebut hasilnya berpengaruh signifikan terhadap penggunaan informasi akuntasi.

Hasil Uji Parsial (t-test)

Berbeda pengujian secara simultan, pengujian ini yaitu parsial bertujuan untuk menghitung masing-masing hasil variabel bebas terhadap variabel terikat. Berikut berupa hasilnya, yaitu.

Coefficients $^{\mathrm{a}}$

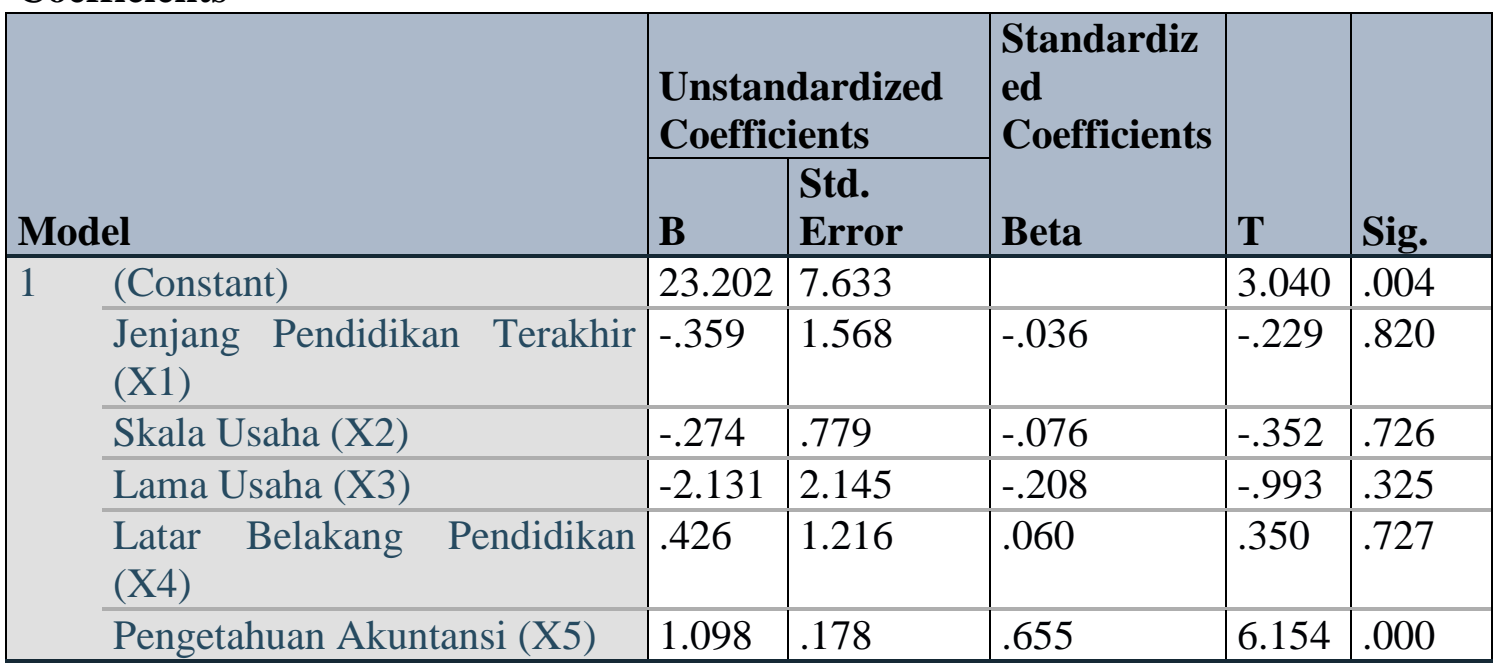




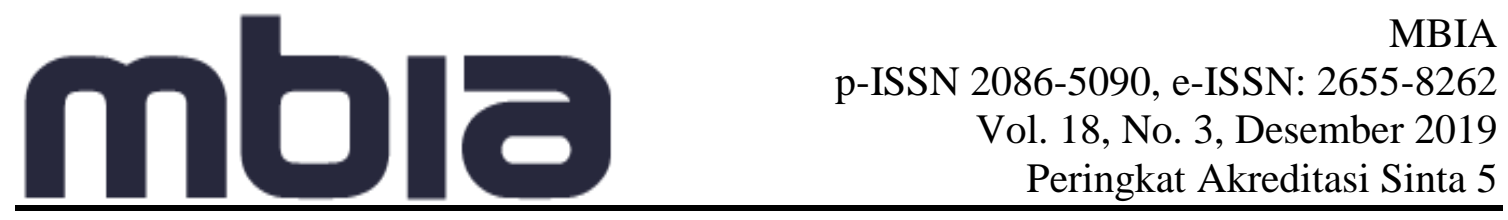

Sumber: Hasil Output SPSS, 2019

Dapat dilihat dari tabel diatas, bahwa secara sendiri-sendiri atau secara parsial untuk variabel jenjang pendidikan terkhir, skala usaha, lama usaha, dan latar belakang pendidikan hasilnya tidak berpengaruh signifikan terhadap penggunaan informasi akuntansi. Sementara itu untuk variabel lainnya yaitu pengetahuan akuntansi hasilnya berpengaruh signifikan terhadap penggunaan informasi akuntansi.

\section{Simpulan}

Setelah dilakukan pembahasan dan menghitung hasil analisis menggunakan pengelolahan data SPSS, maka bisa diambil kesimpulan sebagai berikut. Bahwa secara bersama-sama atau secara simultan hasilnya berpengaruh signifikan terhadap variabel dependen, sedangkan secara sendiri-sendiri atau secara parsial yaitu jenjang pendidikan terakhir, skala usaha, lama usaha, dan latar belakang pendidikan hasilnya tidak berpengaruh signifikan terhadap variabel dependen, sedangkan variabel lainnya yaitu pengetahuan akuntansi hasilnya berpengaruh signifikan terhadap variabel dependen yaitu penggunaan informasi akuntansi.

Sehubungan degan kesimpulan diatas, maka penulis memberikan saran sebagai berikut, yaitu untuk tidak hanya mengandalkan pendidikan yang tinggi, namun pemahaman mengenai informasi akuntansi harus bersifat luas dimiliki. Perlu adanya peningkatan aset, karyawan dan juga penjualan agar hasilnya lebih memuaskan. Perlu suatu peningkatan kondisi perusahaan berupa membangun lamanya usaha UMKM beserta berkembangnya pemahaman yang didapat berupa informasi akuntansi. Dan tidak terfokus kedalam satu bidang saja berupa latar belakang pendidikan, namun bidang-bidang lainnya perlu diperhatikan untuk mempunyai kesempatan besar untuk ditempatkan ke bagian yang diperlukan.

\section{Daftar Pustaka}

Aufar, Arizali. (2013). "Faktor-Faktor Yang Mempengaruhi Penggunaan Informasi Akuntansi Pada UMKM.” Fakultas Ekonomi Program Studi Akuntansi: Universitas Widyatama Bandung

Bahri, Shayful. (2016). "Pengantar Akuntansi Berdasarkan SAK ETAP dan IFRS. “ Edisi 1. Yogyakarta

Farras, Bernhart. 2019. UMKM Kalah Saing Jokowi Beberkan Masalahnya. [Online]. https://www.cnbcindonesia.com/news/20190111134416-4-50214/umkm-kalahsaing-jokowi-beberkan-masalahnya (Diakses Tanggal 11 January 2019 13:56)

Holmess, Scott and Nicholls, Des. 1989. "Modelling The Accounting Information Requirementof Small Business". Accounting and Business Research, Vol. 19. No.74. pp.143-150

Kementrian Koperasi dan UMKM. 2017

Oktasari, Pini, Dian. (2018). “Analisis Laporan Keuangan Untuk Mengukur Kinerja Keuangan Pada Perusahaan Daerah Air Minum (PDAM) Tirta Musi Kota Palembang” Progran Studi manajemen: Universitas Bina Darma Palembang (Penelitii Tidak Dipublikasi) 
Rijanto Erwin. (2015). "Profil Bisnis Usaha Mikro, Kecil, Dan Menengah (UMKM)." Bank Indonesia

Undang-Undang Republik Indonesia Nomor 20 Tahun 2008 “Tentang Usaha Mikro, Kecil, dan Menengah"

Wulandari, Dwi, Anggraini, Vivi. (2016). "Pengaruh Jenjang Pendidikan, Lama Usaha, Skala Usaha, Dan Pengetahuan Akuntansi Terhadap Penggunaan Informasi Pada UMKM Mebel Di Kabupaten Sragen”. Jurusan Akuntansi Syariah

\section{Copyright Disclaimer}

Copyright for this article is retained by the author(s), with first publication rights granted to the journal. 